Kinga Dobosz, Julia Tuszer-Kunc, Dagmara Kulasa, SYLWIA ŚLIWIŃSKA-WILCZEWSKA

Instytut Oceanografii

Wydzial Oceanografii i Geografii

Uniwersytet Gdański

Al. M. Pitsudskiego 46, 81-378 Gdynia

E-mail: dobosh1994@gmail.com

\title{
WYKORZYSTANIE SINIC W HODOWLACH MASOWYCH
}

\section{HODOWLE MASOWE SINIC}

Sinice (Cyanobacteria) posiadaja wiele pozytywnych cech, które kwalifikuja je jako potencjalne źródło biomasy, m.in. dzięki wysokiej wydajności fotosyntetycznej, która przekłada się na szybki wzrost liczebności ich komórek (ALFEUS 2016).

Mimo złej opinii, jaka mają sinice $\mathrm{w}$ zwiazku $z$ toksycznymi zakwitami, hodowla tych organizmów jest niezwykle przyjazna dla środowiska. Większość masowych upraw rolniczych wymaga dużych nakładów słodkiej wody oraz niebezpiecznych i toksycznych dla środowiska nawozów sztucznych. Tymczasem sinice nie potrzebuja żadnego $z$ tych dwóch elementów, ponieważ ich wymagania środowiskowe sa stosunkowo niewielkie. W sprzyjajacych warunkach podziały komórkowe odbywaja się nawet co kilka godzin (WERLE i wspólaut. 2013).

Według Pade i Hagemann (2014), to ewolucja efektywnego mechanizmu przystosowywania się do zmian zasolenia umożliwiła sinicom kolonizacje siedlisk charakteryzujacych się zasoleniem zarówno niskim, jak i wysokim. Autorzy twierdza również, że masowa produkcja sinic powinna odbywać się w wodzie słonej, aby uniknać problemu z dostępem i wykorzystywaniem zasobów wody słodkiej, które i tak sa niewielkie. Dzięki temu gatunki, które przystosowane sa do wzrostu w wodzie o wysokim zasoleniu, a także o wysokiej tolerancji na dostępność światła i zmiany temperatury, stana się wyjściowym punktem do wyizolowania wysoce produktywnych szczepów sinic.
Hodowla sinic może być prowadzona zarówno w otwartych basenach, jak i tzw. foto-bioreaktorach (LEE 2001, IGLIŃSKI i współaut. 2011, PANDEY i współaut. 2013). Hodowle prowadzone na otwartej przestrzeni sa tańsze, ale narażone na silny wpływ czynników zewnętrznych oraz dopływ zanieczyszczeń przenoszonych m.in. przez wiatr (TREDICI 2010). W hodowlach zamkniętych (bioreaktorach) łatwiej utrzymać hodowlę monokulturowa mikroglonów lub sinic oraz na bieżąco kontrolować parametry wody. W tego typu hodowli możliwe jest także osiągnięcie większej wydajności w porównaniu do otwartych basenów hodowlanych (LEE 2001).

Nowe narzędzia i metody, które pozwola na lepsze zrozumienie całego procesu metabolicznego zachodzacego w sinicach, umożliwia stworzenie bardziej wydajnych i opłacalnych systemów produkcji tych organizmów, jako źródeł paliw odnawialnych, surowców chemicznych lub innych wysoce wartościowych produktów (PADE i HAGEMANN 2014).

\section{ROLA SINIC W PRZEMYŚLE SPOŻYWCZYM}

Wzmianki o stosowaniu sinicy Arthrospira sp. pojawiaja się już w XVI w., kiedy korzystali $z$ niej Aztekowie. Do dzisiaj wiele plemion używa sinic jako dobrze zbilansowanego pokarmu. Masowe hodowle sinic w celach spożywczych rozpoczęły się już w latach 70. XX w. Od tamtego czasu preparaty $z$ Arthrospira sp. (m. in. A. maxima $i A$. platensis) sprzedawane sa na 
całym świecie pod nazwa "spirulina”, a kraje, które produkuja ja w największych ilościach to m.in. USA (firma Earthrise Farms I Cyanotech), Chiny (firma Hainan DIC Microalgae Co., Ltd), Indie (firma Marugappa Chettir Research Center), Kuba (firma Genix) i Chile (firma Solarium Biotechnology). Suplementy te dostępne sa w postaci tabletek, proszków, a nawet chipsów, zarówno w aptekach, sklepach zielarskich oraz dużych marketach ze zdrowa żywnością (MIKLASZEWSKA i współaut. 2008).

„Spirulina” może być ważnym składnikiem diety, ponieważ stanowi bogate źródło białka. Badania potwierdzaja, że białka stanowia 60\% suchej masy sinic (PRASANNA i współaut. 2010), a ich zawartość zależy od warunków hodowli konkretnych gatunków (A. platensis i A. maxima). Wykonane przez CIFFERI (1983) analizy wykazały, że organizmy hodowane $\mathrm{w}$ laboratorium zawierały dużo więcej białka niż te, które pochodziły $z$ otwartych zbiorników, charakteryzujacych się wyższa zawartością węglowodanów. Ponadto, sinice zawieraja wiele aminokwasów niezbędnych $\mathrm{w}$ zdrowej diecie, dzięki czemu sa one na szeroka skalę wykorzystywane do produkcji żywności. Codzienne spożywanie odpowiedniej ilości biomasy Arthrospi$\mathrm{ra}$ sp. uzupełnienia deficyt białek i innych ważnych substancji, potrzebnych dla prawidłowego funkcjonowania organizmu (MiKLASZEWSKA i współaut. 2008). Sinice należące do tego rodzaju moga pomóc $\mathrm{w}$ rozwiąaniu kolejnego problemu ludzkości, jakim jest otyłość, ponieważ zawieraja zwiazki obniżajace poziom cholesterolu we krwi. Dodatkowo, hodowla Arthrospira sp. jest łatwa i stosunkowo tania, co przekłada się na duże zyski m.in. $z$ masowej hodowli glonów (około $30 \%$ ), która przeznaczana jest na produkcję pożywienia (KAMJUNKE i współaut. 2002).

Organizmy te sa również coraz częściej stosowane $\mathrm{w}$ celu zwiększenia wartości odżywczej pasz dla zwierząt, ze względu na ich dobrze wyważony skład chemiczny. Udowodnione zostało, że dodawanie masowo hodowanych sinic $z$ gatunku Microcystis sp. do pokarmu ryb, wpływa na ich szybszy wzrost oraz zwiększona produkcję glikogenu w wątrobie (KAMJUNKE i współaut. 2002).

Ponadto, sinice zawieraja cenne barwniki fikobilinowe, które są szeroko wykorzystywane jako barwnik spożywczy. Niebieski pigment (fikocyjanina) został już skomercjalizowany $\mathrm{w}$ Japonii, jako pigment żywnościowy, podczas gdy ksantofil (zeaksantyna), okazał się skuteczny w zwiększaniu pigmentacji ryb i krewetek (MORI i współaut. 1987).

\section{SINICE W PRZEMYŚLE MEDYCZNYM}

Identyfikacja nowych produktów naturalnego pochodzenia jest ważnym krokiem w odkrywaniu nowych źródeł leków, mających szerokie spektrum zastosowania (COSTA i współaut. 2014). Uważa się, że sinica $A$. platensis może być ważnym obiektem badań biotechnologicznych, ze względu na jej wartość ekonomiczna, ekologiczną i żywieniowa (PELIZER i współaut. 2003). A. platensis może wytwarzać duże ilości bogatych wartościowo barwników fotosyntetycznych zwanych fikobilinami (CHEN i ZHANG 2003), które można podzielić na fikocyjaninę (kolor niebieski) oraz fikoerytrynę (charakteryzujacą się barwą czerwona) (ABALDE i współaut. 1998). Fikocyjanina jest głównym pigmentem wytwarzanym przez sinice A. platensis i może stanowić nawet $20 \%$ suchej masy komórki (VONSHAK 1997). Potencjalnie może być stosowana jako środek terapeutyczny w leczeniu chorób oksydacyjnych. Obecna tendencja stosowania naturalnych pigmentów uczyniła $z$ fikocyjaniny atrakcyjny bioprodukt. W Europie coraz intensywniej poszukuje się naturalnych składników, ponieważ wytwarzane syntetyki sa na ogół uważane za toksyczne, a także niebezpieczne dla człowieka i środowiska (BELLISLE i współaut. 1998).

Spirulina zasługuje na szczególna uwage ze względu na jej właściwości nutraceutyczne, czyli produktu spożywczego, który łączy w sobie właściwości żywieniowe i farmaceutyczne. Skład chemiczny spiruliny wskazuje, że ma wysoka wartość odżywczą ze względu na zawartość niezbędnych składników, takich jak: witaminy, minerały, białka i wielonienasycone thuszcze oraz kwasy takie jak kwas $\gamma$-linolenowy GLA (MIRANDA i współaut. 1998). A. platensis stanowi bogate źródło witamin $z$ grupy B (B1, B2, B6 i B12) oraz C, $\mathrm{E}, \mathrm{PP}$ (niacyna), a także minerałów: $\mathrm{P}, \mathrm{Fe}$, $\mathrm{Ca}, \mathrm{K}, \mathrm{Na}, \mathrm{Mg}$. Zawiera również kwas foliowy, kwas pantotenowy i inozytol oraz barwniki. Odkad zwrócono uwage na jej specjalne właściwości, przeprowadzono wiele badań umożliwiających i tłumaczacych jej zastosowanie (YANG i współaut. 2012).

Spirulina została również przebadana na obecność zwiąków przeciwutleniających, takich jak fenole (ESTRADA i współaut. 2001, MiRANDA i współaut. 1998). Występowanie fenolu w roślinach i jego aktywność antyoksydacyjna jest bardzo dobrze udokumentowana, natomiast właściwości przeciwutleniające sinic sa mniej poznane. U pacjentów z hipercholesterolemia, czyli podwyższonym poziomem złego cholesterolu (LDL), podawano spirulinę jako suplement diety. Zaobserwowano, że zawartość LDL we krwi pacjen- 
tów uległa obniżeniu (RAMAMOORTHY i PREMAKUMARI 1996). Dodatkowo wykazano, że fikobiliproteiny wyodrębnione $z$ A. platensis wykazuja aktywność antyoksydacyjna (ESTRADA i współaut. 2001).

Sinica $A$. platensis jest również jednym $Z$ najbardziej obiecujących źródeł wielonienasyconego kwasu tłuszczowego $\gamma$-linolenowego. Jego brak w organizmie powoduje, że skóra staje się sucha i traci swoja elastyczność, co przyspiesza tworzenie się zmarszczek. Niedobór tego kwasu sprawia, że naturalna odporność skóry na szkodliwe działanie czynników zewnętrznych zanika, a proces gojenia się ran i pęknięć naskórka zachodzi wolniej (BOJANOWICZ i WOŹNIAK 2008). Dzięki badaniom TANTICHAROEN i współaut. (1994) wiadomo, że zawartość GLA w spirulinie może osiagnąć 31,7\% kwasów tłuszczowych i $1,4 \%$ biomasy (suchej masy), co udowadnia, że zawartość GLA w sinicach jest największa $\mathrm{w}$ porównaniu $z$ innymi mikroglonami. Spirulina posiada także właściwości przeciwzapalne i neowaskularyzacyjne, co pokazuja badania prowadzone na myszach. Wcześniej poparzone roztworem $\mathrm{NaOH}$ oczy zwierzat przemywano ekstraktem ze spiruliny przez 7 dni. Wyniki badań udowodniły, że ekstrakt ze spiruliny hamuje ekspresję czynników, takich jak: VEGF (czynnik wzrostu śródbłonka naczyniowego), MMP2 (metaloproteinaza macierzy 2) i MMP9 (metaloproteinaza macierzy 9), natomiast stymuluje ekspresję PEDF (pigment pochodzacy $z$ nabłonka pigmentowego). Tak więc spirulina może hamować CNV (neowaskularyzacja naczyniówki czyli tworzenie nowych naczyń krwionośnych w warstwie naczyniówki oka) poprzez zmniejszenie ilości czynników bioracych udział w procesie powstawania naczyń włosowatych w angiogenezie, oraz jednoczesną aktywację czynników ją hamujacych (YANG i współaut. 2012).

Wpływ spiruliny na mediatory stanu zapalnego badano przy użyciu myszy albinosów obu płci, u których wywołano reumatoidalne zapalenie stawów za pomoca adiuwantów, które służa do wzmocnienia poszczepiennej odpowiedzi odpornościowej na podany antygen. Część zwierząt otrzymywała "spirulinę" przez 8 dni. Badania wykazały, że ekstrakt ze "spiruliny” hamował obrzęk kończyn, co spowodowane było spadkiem poziomu hydrolaz lizosomalnych. Uważa się, że zmniejszenie obrzęku dzięki "spirulinie" zwiazane jest $z$ jej ingerencja w przemiany cyklicznej oksygenazy (RAsOOL i współaut. 2006).

$\mathrm{Z}$ kolei przeprowadzone badanie in vitro przez HAYASHI i współaut. (1996) dowiodły, że spirulina posiada właściwości przeciwwirusowe. Wyekstrahowano $z$ niej polisacharyd zawierajacy reszty kwasu siarkowego (VI), spirulan wapnia (Ca-SP), który wykorzystano jako materiał do badań. Okazało się, że spirulan wapnia wykazuje przeciwwirusowe właściwości w stosunku do wirusa HIV-1, HSV-1 i ludzkiego wirusa cytomegalii. Mechanizm, blokujacy replikację wirusa, polega na hamowaniu połaczenia się wirusa $z$ komórka gospodarza i ich późniejszej fuzji.

$\mathrm{W}$ innych badaniach sprawdzano także właściwości przeciwbakteryjne spiruliny. Testy wykazały, że ekstrakt ze spiruliny przyspieszył wzrost bakterii mlekowych, które sa zaliczane do organizmów probiotycznych, wspomagajacych utrzymywanie równowagi pomiędzy szkodliwymi i korzystnymi mikroorganizmami w przewodzie pokarmowym, dzięki czemu poprawione zostaje wchłanianie jelitowe. Podobnie we wcześniejszych badaniach, ekstrakt ze spiruliny hamował rozwój bakterii patogennych (BHOWMIK i współaut. 2009).

Jednak nie tylko A. platensis może być źródłem cennych produktów wykorzystywanych w przemyśle medycznym czy farmaceutycznym. CosTA i współaut. (2014) wykazali, że pikoplanktonowe, morskie sinice należące do rodzajów: Cyanobium, Synechocystis, Synechococcus oraz formy nitkowate z rodzajów: Nodosilinea, Leptolyngbya, Pseudanabaena i Romeria mają duży potencjał jako źródło związków o charakterze przeciwnowotworowym. Dodatkowo, MUNDT i współaut. (2014) twierdzą, że wtórne metabolity sinic (tzw. paracyklofany) moga być potencjalnie wykorzystywane w produkcji antybiotyków. Zwiąki te produkowane sa przez różne gatunki sinic i moga być izolowane w postaci czystego związu $z$ wydajnościa 0,1 do $0,2 \%$. Sa one też biologicznie aktywne w stosunku do bakterii opornych na wiele rodzajów leków.

\section{WYKORZYSTANIE SINIC W PRZEMYŚLE KOSMETYCZNYM}

W przemyśle kosmetycznym ekstrakty roślinne zostały uznane za substancje mogące wspierać ochronę antyoksydacyjną organizmu, stąd też pojawiły się pomysły, aby wykorzystywać je jako foto-ochronne składniki produktów kosmetycznych (ALMEIDA i współaut. 2015). Dodatkowo, w sinicach wykryto zdolność syntezy związów chroniacych przed promieniowaniem UV (RASTOGI i współaut. 2010). W zwiazku $z$ tym sa one dobrym źródłem pozyskiwania środków zapewniających ochronę przed UV, wykorzystywanych w kosmetykach (ALFEUS 2016). Jako przykład można podać aminokwas „porphyra 334", wyizolowany $z$ sinicy Aphanizomenon flos-aquae, który po dodaniu do produktów 
chroniacych przed promieniowaniem słonecznym dwóch znanych marek (Nivea i Boots) sprawił, że stały się one bardziej efektywne (TORRES i współaut. 2006). Kolejnym związkiem pozyskiwanym $z$ sinicy, który może zaistnieć jako środek chroniący przed promieniowaniem UV, jest scytonemina wyizolowany z sinicy Stigonema spp. (KARLSSON 2011).

Sinica A. platensis wykorzystywana jest także do barwienia produktów kosmetycznych w sposób naturalny (BELLISLE i współaut. 1998). Ze względu na dużą zawartość witamin, minerałów, kwasu foliowego, pantotenowego, a także aminokwasów (YANG i współaut. 2012) jest to gatunek najczęściej wykorzystywany w produkcji kosmetyków takich jak: kremy do twarzy, maseczki czy toniki. Obecnie większość marek kosmetycznych ma $\mathrm{w}$ ofercie produkt zawierajacy $\mathrm{w}$ swoim składzie zwiąki pochodzace $z$ mikroglonów, a w szczególności z sinic. Organizmy te wykorzystywane sa także w suplementach diety, majacych poprawiać kondycję skóry, włosów i paznokci, często w połączeniu ze słodkowodna zielenica Chlorella sp. lub młodym jęczmieniem.

\section{WYKORZYSTANIE ZWIAZKÓW SINIC W ROLNICTWIE}

Metabolity sinic moga mieć również zastosowanie jako herbicydy i insektycydy (BERRY i współaut. 2008). Szacuje się, że na komercyjne zastosowanie herbicydów i insektycydów Stany Zjednoczone wydaja kilka miliardów dolarów rocznie (PENG i współaut. 2003). Dlatego w ostatnich dziesięcioleciach prowadzono wiele badań analizujacych rolę sinic jako biologicznego środka zwalczajacego szkodniki i wykorzystanie ich na rzecz zrównoważonego rolnictwa (SODAEIZADEH i HOSSEINI 2012). Wytwarzane przez sinice zwiazki sa zatem potencjalnym źródłem alternatywnych rozwiązań i staja się nową strategia w rolnictwie.

Sinice moga być bardzo efektywne jeśli chodzi o wzbogacanie gleby $\mathrm{w}$ węgiel organiczny i azot, a także zwiększanie biodostępności związów fosforu dla uprawianych roślin. Sa także idealnym źródłem różnorodnych bioaktywnych związków o wyraźnych właściwościach antagonistycznych (Singh J. i współaut. 2016). W zwiazku z wprowadzaniem zrównoważonego rolnictwa istnieje ogromny potencjał rozwoju organizmów które dbaja o odpowiednia ilość składników odżywczych w glebie oraz biologiczna kontrolę szkodników i chorób, co ostatecznie może prowadzić do obniżenia kosztów uprawy. Do grupy tej należa również sinice (SINGH 2013, SingH i SingH 2013).
W ostatnich latach wiele uwagi poświęcono zastosowaniu wtórnych metabolitów sinic jako naturalnego środka chemicznego, służacego do zwalczania larw komarów (HARADA i współaut. 2000). Dane literaturowe wskazuja, że choroby przenoszone przez komary (m. in. malaria, źółta febra, gorączka denga, różne formy zapalenia opon mózgowych, wirus goraczki zachodniego Nilu) zabijają każdego roku miliony ludzi na całym świecie i stanowia coraz poważniejszy problem (GUBLER 1998). Sinice to często główny składnik diety larw komarów (VAZQUEZ-MARTINEZ i współaut. 2002). Mając na uwadze zdolność sinic do wytwarzania metabolitów, które odstraszaja i hamuja wzrost drapieżników, sugeruje się, że produkcja takich związków przez słodkowodne sinice może stanowić potencjalne źródło ochrony przed komarami. RAGHUNATHA RAO i współaut. (1999) zaobserwowali, że metanolowy ekstrakt $\mathrm{z}$ sinicy Westiellopsis sp. był larwobójczy dla Anophele saegypti (przenoszacej goraczkę denga), Anopheles stephensi (przenoszacej malarię) oraz Culex tritaeniorhyncus i Culex quinquefaciatus (powodujacych zapalenie opon mózgowych). Również HARADA i współaut. (2000) scharakteryzowali mieszaninę kwasów tłuszczowych ze szczepu Oscillatoria agardhii, która hamowała wzrost larw $\mathrm{z}$ gatunku Aedes albopictus, blisko spokrewnionych $z A$. aegypti. Odkrycie to jest szczególnie ważne, ponieważ zidentyfikowane związki należały do kwasów tłuszczowych, które w żaden sposób nie sa szkodliwe dla ssaków (BERRY i współaut. 2008).

\section{SINICE A BIOENERGETYKA}

W społeczeństwie nadal istnieje potrzeba stosowania nieodnawialnych źródeł energii, a dodatkowo, wraz $z$ rozwojem technologicznym, wzrasta zapotrzebowanie na energię. Dzisiejsza produkcja paliw płynnych na świecie niemal całkowicie zależy od ropy naftowej. Dlatego mikroglony staja się coraz bardziej docenianym substratem $\mathrm{w}$ produkcji biopaliw. Dostrzegalny jest wzrost zainteresowania produkcja biopaliw zwiazany $z$ rozwojem bioreaktorów i inżynieria bioenergetyki. Rozwój tej gałęzi może zwiększyć światowe bezpieczeństwo paliwowe oraz zmniejszyć problem wydzielanego do atmosfery dwutlenku węgla. Dodatkowo, są to źródła naturalne i odnawialne, w odróżnieniu od wydobywanego gazu ziemnego, ropy naftowej czy węgla kamiennego (LARKUM i współaut. 2012).

Badania nad biopaliwem to nie tylko kwestia znalezienia właściwych organizmów tworzacych dużą biomasę w szybkim czasie. Ważnym parametrem jest możliwość 
przekształcenia zawartych w nich substancji w paliwo czy stworzenia na ich podstawie biogazu. Produkcja biopaliw musi być także zrównoważona ekonomicznie (PARMAR i współaut. 2011). Dyskusja nad produkcją biopaliw koncentruje się na wykorzystaniu wyższych roślinach, takich jak kukurydza, trzcina cukrowa, soja, olej palmowy i inne (GNANSOUNOU i współaut. 2008, PANDEY 2008), a także na problemach związanych $z$ ich używaniem, takich jak utrata ekosystemów lub wzrost cen żywności.

Obecnie do głównych biopaliw na rynku światowym zalicza się biowodór, bioetanol, biodiesel i biogaz (PARMAR i współaut. 2011). Biodiesel to przetworzone chemicznie oleje roślinne do silników wysokoprężnych. Moga one być wytwarzane w reakcjach chemicznych lipidów (olej roślinny, tłuszcz zwierzęcy) $z$ alkoholem, co w połaczeniu daje kwasy tłuszczowe. Biowodór jest bardziej atrakcyjnym biopaliwem do użytku w przyszłości, nie powodujacym zanieczyszczenia i ma charakter niewyczerpalny. Etanol, czyli alkohol etylowy, jest lotna, łatwopalna, bezbarwna ciecza, którą wytwarza się przez fermentację cukru przez mikroorganizmy. Badania dowodza, że sinice w kontrolowanych warunkach łatwo ulegaja fermentacji (SINGH V. i współaut. 2016), co daje duże możliwości związane $z$ wykorzystaniem poszczególnych ich gatunków jako substratu do pozyskiwania zielonej energii.

Sinice odgrywają znacząca rolę w globalnej sekwestracji dwutlenku węgla, produkcji tlenu i w cyklu azotowym (PARMAR i współaut. 2011). Dzięki możliwościom przeprowadzania fotosyntezy moga przekształcać do $10 \%$ energii słońca na biomasę, w porównaniu do $1 \%$ odnotowanego u kukurydzy i trzciny cukrowej, czy 5\% osiaganych przez inne mikroglony (LI i współaut. 2008).

Obecnie do produkcji bioenergii używa się głównie kilku gatunków sinic ( $z$ rodzaju
Synechocystis i Synechococcus), inne bada się pod kątem możliwości pozyskiwania $z$ nich energii. Podstawowymi parametrami jest ilość tłuszczu w komórkach sinic w stosunku do ich wielkości. W zależności od gatunku możemy uzyskać różną ilość substancji energetycznych (SingH V. i współaut. 2016).

Tabela 1 przedstawia produktywność wytwarzania biowodoru przez poszczególne gatunki sinic. Widoczna jest duża różnorodność w zależności od badanego gatunku, a różnice dotyczą budowy komórki, jej wielkości, aktywności enzymów, efektywności fotosyntezy oraz rodzaju modyfikacji, która przeprowadza się na wybranych gatunkach w celu zwiększenia wydajności.

W Tabeli 2 zawarto wykaz zwiąków, które pozyskiwane są $z$ sinic należacych do rodzaju Synechocystis sp. Wszystkie te substancje sa substratami energetycznymi. Zauważalne są dość duże różnice w wartości wyznaczonego współczynnika produktywności. Najwięcej oznaczono 1-butanolu, który został zaproponowany jako substytut oleju napędowego i benzyny ze względu na niską higroskopijność i wysoką wartość energetyczną uzyskiwana $\mathrm{w}$ procesie spalania. Izobutanol jest dobrym kandydatem do zastapienie benzyny ze względu na niską higroskopijność, dużą ilość energii wytwarzanej podczas spalania i kompatybilność $z$ istniejacca już technologia pozyskiwania energii. Izopren jest biogazem, który powstaje jako produkt uboczny. Jednak bioreaktory musza być odpowiednio przygotowane do tego, aby można było efektywnie pozyskiwać ten substrat energetyczny (MACHADO i ATSUMI 2012).

Niestety badania dotyczace uzyskania biopaliw $z$ sinic są wcią̇ słabo rozwinięte. Sinice maja wiele zalet $w$ porównaniu $z$ tradycyjnymi roślinami energetycznymi, jednak masowa produkcja na skalę globalna nie jest obecnie technicznie możliwa. W

Tabela 1. Produkcja biowodoru w zmodyfikowanych sinicach.

\begin{tabular}{lll}
\hline Gatunek oraz szczep sinicy & $\begin{array}{l}\text { Produktywność } \\
{\left[\mu \mathrm{mol} \mathrm{H} \mathrm{H}_{2} /(\mathrm{mg} \mathrm{Chl} \cdot \mathrm{h})^{-1}\right]}\end{array}$ & Referencje \\
\hline Synechococcus sp. PCC7002 & 1,2 & (SRIRANGAN i współaut. 2011) \\
Anabaena sp.PCC7120 & 50 & (MASUKAwA i współaut. 2002) \\
Synechocystis sp. PCC6803 & 6 & (COURNAC i współaut. 2004) \\
Nostoc sp. PCC7422 & 100 & (YosHINo i współaut. 2007) \\
Anabaena variabilis ATCC29413 & 12,6 & (HAPPE i współaut. 2000) \\
Cyanothece sp. ATCC51142 & 400 & (MIELNICKI i współaut. 2012) \\
Nostoc linckia HA-46 & $93-105$ & (MonA i współaut. 2011) \\
\hline
\end{tabular}


Tabela 2. Produkty chemiczne syntetyzowane przez zmodyfikowane sinice.

\begin{tabular}{|c|c|c|c|}
\hline Produkt & $\begin{array}{l}\text { Współczynnik produk- } \\
\text { tywności }\left[\mu \mathrm{g} \cdot \mathrm{g}^{-1} \cdot \mathrm{h}^{-1}\right]\end{array}$ & Gatunek & Referencje \\
\hline 1-Butanol & 78,33 & $\begin{array}{l}\text { Synechococcus elongatus } \\
\text { PCC } 7942\end{array}$ & (LAN i LIAO 2011) \\
\hline Izopren & 2,08 & Synechocystis sp. PCC6803 & (LINDBERG i współaut. 2010) \\
\hline Izobutyraldehyd & 6,23 & $\begin{array}{l}\text { Synechococcus elongatus } \\
\text { PCC } 7942\end{array}$ & (ATsumi i współaut. 2009) \\
\hline Izobutanol & 3,12 & $\begin{array}{l}\text { Synechococcus elongatus } \\
\text { PCC } 7942\end{array}$ & (ATSUMI i współaut. 2009) \\
\hline
\end{tabular}

przyszłości sinice moga odgrywać znaczacaca rolę w pozyskiwaniu alternatywnych zasobów energetycznych, niwelowaniu globalnego ocieplenia oraz poprawie zdrowia ludzkiego i bezpieczeństwa żywnościowego (PARMAR i współaut. 2011). Przyszłe badania musza uwzględniać udoskonalenie szczepu, aby osiagnąć wysoka wydajność, utrzymać tempo wzrostu i poprawić potencjał komórek do przeżycia w niekorzystnych warunkach (MACHADO i ATSUMI 2012). Według SingH V. i współaut. (2016), w przyszłości inżynieria genetyczna i badania nad metabolizmem odegraja ważna rolę w poprawie ekonomiki produkcji biopaliw $z$ wykorzystaniem sinic.

\section{PODSUMOWANIE}

Hodowle masowe sinic maja ogromny potencjał gospodarczy. Sinice, ze względu na dużą zawartość związków odżywczych, są bardzo dobrym źródłem pożywienia zarówno dla ludzi, jak i zwierząt. Dodatkowo, znaczna zawartość witamin i minerałów oraz innych związków niezbędnych do prawidłowego funkcjonowania organizmu wpływa na fakt, że sinice coraz częściej wykorzystywane sa w przemyśle farmaceutycznym, medycynie i produkcji kosmetyków. Związki wytwarzane w ich procesach metabolicznych sa także potencjalnym źródłem alternatywnych rozwiązań w walce $z$ insektami i chwastami, co sprawia, że zyskują one coraz większe znaczenie w rolnictwie. Wiadomo również, że światowe zapotrzebowanie na energie ciagle wzrasta, a niektóre gatunki sinic o dużej zawartości tłuszczów, moga stać się źródłem energii odnawialnej. Przedstawione informacje tylko w małym stopniu opisuja potencjał sinic, a dalsze badania tej grupy mikroorganizmów pozwola na odkrywanie nowych możliwości wykorzystania ich w różnych sektorach przemysłu.

\section{Streszczenie}

Masowa hodowla sinic ma swoje poczatki już w XVI w. W ostatnich latach zyskuje ona na popularności ze względu na szybki wzrost i małe wymagania środowiskowe, a także szczególne właściwości tych mikroorganizmów. Sinice zawierają duże ilości witamin, minerałów, białek oraz wielonienasyconych kwasów tłuszczowych. Wykorzystuje się je w przemyśle spożywczym oraz w produkcji różnych kosmetyków, leków, jak również w technologiach oczyszczania ścieków czy usuwania zwiazków biogennych. Najczęściej wykorzystywanym gatunkiem jest Arthrospira platensis, powszechnie znana jako spirulina, która ma dużą wartość ekonomiczna, ekologiczna oraz żywieniowa. Niektóre sinice, ze względu na szybki przyrost biomasy stosowane sa jako pokarm dla zwierzat. Odkryto także, że metabolity tej grupy organizmów moga mieć zastosowanie jako herbicydy i insektycydy, przez co można przypisać im również istotna rolę $\mathrm{w}$ rolnictwie. Istnieją także gatunki sinic, które bada się szczególnie pod kątem wykorzystania ich w produkcji biopaliwa, aby mogłyby stanowić źródło energii odnawialnej.

\section{LITERATURA}

Abalde J., Betancourt L., Torres E., Cid A, BARWELL C., 1998. Purification and characterization of phycocyanin from the marine cyanobacterium Synechococcus sp. Plant Sci. 136, 109-120.

ALFEUS A., 2016. Cyanobacteria as a source of compounds with cosmetics potential. Praca magisterska. Institute of Biomedical Sciences of Abel Salazar from the University of Porto.

Almeida I. F., PinTo A. S., MONTEIRO C., MONteiro H., Belo L., Fernandes J., Bento A. R., DUARTET. L., GARRIDO J., BAHIA M. F., LOBO J. S., COSTA P. C., 2015. Protective effect of C. sativa leaf extract against UV mediated-DNA damage in a human keratinocyte cell line. J. Photochem. Photobiol. B, Biol. 144, 28-34.

Atsumi S., Higashide W., LiaO J. C., 2009. Direct photosynthetic recycling of carbon dioxide to isobutyraldehyde. Nat. Biotechnol. 27, 11771180 .

Bellisle F., Blundell T. E., Dye L., Fantino M., FERN E., Fletcher R. J., LAMBERT J., ROBERFROID M., SPECTER S., WESTNHOFER J., WESTERTERTERP-PLANTENGA M. S, 1998. Functional food science and behaviour and psychological functions. Brit. J. Nutriti. 80, 419-435.

BerRy J. P., Gantar M., Perez M. H., BerRY G., NorIEGA F. G., 2008. Cyanobacterial toxins as allelochemicals with potential applications as algaecides, herbicides and insecticides. Marine Drugs 6.2, 117-146.

BhowmiK D., Dubey J., Mehra S., 2009. Probiotic efficiency of Spirulina platensis - stimulat- 
ing growth of lactic acid bacteria. World J. Dairy Food Sci. 4, 160-163.

BOJANOWICZ H., WOŹNIAK B., 2008. Wielonienasycone kwasy tłuszczowe oraz ich wpływ na skórę. Problemy Higieny i Epidemiologii 89, 471475.

CHEN F., ZHANG Y., 2003. High cell density mixotrophic culture of Spirulina platensis on glucose for phycocyanin production using fed-batch system. Enzyme Microb. Technol. 20, 221-224.

CIFERRI O., 1983. Spirulina, the edible microorganism. Microbiol. Rev. 47, 551.

Costa M., Garcia M., Costa-Rodrigues J., Costa M. S., RiBeIRo M. J., FERnANDES M. H., BARROS P., BARREIRO A., VASCONCELOS V., MARTINS R., 2014. Exploring bioactive properties of marine cyanobacteria isolated from the Portuguese coast: high potential as a source of anticancer compounds. Marine Drugs 12, 98-114.

COURnAC L., Guedeney G., Peltier G., VIGNAIS P. M., 2004. Sustained photoevolution of molecular hydrogen in a mutant of Synechocystis sp. strain PCC 6803 deficient in the type I NADPH-dehydrogenase complex. J. Bacteriol. 186, 1737-1746.

Estrada J. P., Bescós P. B., Del Fresno A. V., 2001. Antioxidant activity of different fractions of Spirulina platensis protean extract. Il farmaco 56, 497-500.

GNansounou E., LaRRoche C., PANDEY A., 2008. Biofuels II. J.' Scien. Industr. Res., Special issue $67,837-1040$.

GUBLER D. J., 1998. Resurgent vector-borne diseases as a global health problem. Emerg. Infect. Dis. 4.3, 442.

HAPPE T., SCHÜTZ K., BÖHME H., 2000. Transcriptional and Mutational Analysis of the Uptake Hydrogenase of the Filamentous Cyanobacterium Anabaena variabilis ATCC 29413. J. Bacteriol. 182, 1624-1631.

HARADA K. I., SUOMALAINEN M., UChIDA H., MASUI H., OHMURA K., KIVIRANTA J., IKEMOTO T., 2000. Insecticidal compounds against mosquito larvae from Oscillatoria agardhii strain 27. Environ. Toxicol. Int. J. 15.2, 114-119.

HAYASHI K., HAYASHI T., KOJIMA I., 1996. A natural supfated polysaccharide, calcium spirulan, isolated from Spirulina platensis: In vitro and ex vivo evaluation of Anti-Herpes Simplex Virus and Anti-Human Immunodeficiency Virus activities. AIDS Res. Human Retroviruses 12, 1463-1471.

IgLiŃSKI B., BuczKOwsKI R., PIEchOtA G., 2011. Algi. Źródło energii $i$ substancji chemicznych. Przemysł Chemiczny 90, 1186-1190.

KAMJUNKE N., MENDONCA R., HARDEWIG I., 2002. Assimilation of different cyanobacteria as food and the consequences for internal energy stores of juvenile roach. J. Fish Biol. 60, 731738.

KARLSSON I., 2011. Chemical and dermatological aspects of UV-absorbing compounds. Rozprawa doktorska. Department of Chemistry University of Gothenburg Göteborg, Sweden, http://hdl.handle. net/2077/2666510.10.2017.

LAN E. I., LIAO J.C., 2011. Metabolic engineering of cyanobacteria for 1-butanol production from carbon dioxide. Metab. Engine. 13, 353-363.

LARKUM A. W., ROSS I. L., KRUSE O., HANKAMER B., 2012. Selection, breeding and engineering of microalgae for bioenergy and biofuel production. Trends Biotechnol. 30, 198-205.

LEE Y. K., 2001. Microalgal mass culture systems and methods: Their limitation and potential. J. Appl. Phycol. 13, 307.
Li Y., HoRsman M., Wu N., LAN C. Q., DUBOIS-CALERO N., 2008. Biofuels from microalgae. Biotechnol. Progr. 24, 815-820.

LINDBERG P., PARK S., MELIS A., 2010.Engineering a platform for photosynthetic isoprene production in cyanobacteria, using Synechocystis as the model organism. Metab. Engine. 12, 70-79.

MACHADO I. M., ATSUMI S., 2012. Cyanobacterial biofuel production. J. Biotechnol. 162, 50-56.

Masukawa H., MOchIMARU M., SAKURAI H., 2002. Disruption of the uptake hydrogenase gene, but not of the bidirectional hydrogenase gene, leads to enhanced photobiological hydrogen production by the nitrogen-fixing cyanobacterium Anabaena sp. PCC 7120. Appl. Microbiol. Biotechnol. 58, 618-624.

Melnicki M. R., Pinchuk G. E., Hill E. A., KuCEK L. A., Fredrickson J. K., KonOPKA A., BeLIAEV A. S., 2012. Sustained H2 production driven by photosynthetic water splitting in a unicellular cyanobacterium. mBio 3, e00197-12.

MiKLASZEWSKA M., WALERON M., WALERON K., 2008. Biotechnologiczny potencjat cyjanobakterii $z$ rodzaju Arthrospira. Biotechnologia $3,119-142$.

Miranda M. S., Cintra R. G., BarRos S. B. M., MANCINI-FILHO J., 1998. Antioxidant activity of the microalga Spirulina maxima. Braz. J. Med. Biol. Res. 31, 1075-1079.

Mona S., KaUSHIK A., KaUshiK C. P., 2011. Hydrogen production and metal-dye bioremoval by a Nostoclinckia strain isolated from textile mill oxidation pond. Bioresource Technol. 102, 32003205.

MORI T., Muranaka T., Miki W., Yamaguchi K., Konosu S., Watanabe T., 1987. Pigmentation of cultured sweet smelt fed diets supplemented with a blue-green alga Spirulina maxima. Nippon Suisan Gakkaishi 53, 433-438.

Mundt S., Bui H. T., PREISitsch M., KReitlow S., Bui H. T. N., Pham H. T., Zainuddin E., LE T. T., LukowsKI G., JÜLICH W. D., 2014. Microalgae A promising source of novel therapeutics. JSM Biotechnol. Biomed. Engine. 2, 1032.

PADE N., HAGEMANN M., 2014. Salt acclimation of cyanobacteria and their application in biotechnology. Life 5, 25-49.

PANDEY A., 2008. Handbook of plant-based biofuels. CRC Press, Francis \& Taylor's, Boca Raton, 297.

Pandey V. D., Pandey A., Sharma V., 2013. Biotechnological applications of cyanobacterial phycobiliproteins. Int. J. Curr. Microbiol. Appl. Sci. 2, 89-97.

PARMAR A., Singh N. K., PANDEy A., GnansouNOU E., MADAMWAR D., 2011. Cyanobacteria and microalgae: a positive prospect for biofuels. Bioresource Technol. 102, 10163-10172.

Pelizer L. H., Danesi E. D. G., Rangel C. O., Sassano C. E. N., Carvalho J. C. M., Sato S., MORAES I. O., 2003.Influence of inoculum age and concentration in Spirulina platensis cultivation. J. Food Engine. 56, 371-375.

Peng C., WU G., XI Y., XIA Y., Zhang T., ZHAO Y., 2003. Isolation and identification of three algae-lysing bacteria and their lytic effects on blue-green algae (Cyanobacteria). Res. Environ. Sci. 16, 37-40.

PRASANNA R., SOOD A., JAISWAL P., NAYAK S., GuPTA V., ChaudhaRY V., 2010. Rediscovering Cyanobacteria as valuable sources of bioactive compounds (Review). Appl. Biochem. Microbiol. 46, 119-134.

Raghunatha RaO D., ThangaVel C., Kabilan L., SUguna S., MANI T. R., SHANMUGaSUnDARAM S., 1999. Larvicidal properties of the cyanobac- 
terium Westiellopsis sp.(blue-green algae) against mosquito vectors. Transact. Royal Soc.Trop. Med. Hyg. 93, 232-232.

RAMAMOORTHY A., PREMAKUMARI S., 1996. Effect of supplementation of Spirulina on hypercholesterolemic patients. J. Food Sci. Technol. 33, 124-128.

Rasool M., SaBina E. P., LaVanya B., 2006. Anti-inflammatory effect of Spirulina fusiformis on adjuvant-induced arthritis in mice. Biol. Pharmaceut. Bull. 29, 2483-2487.

RASTOGI R. P., SinHa R. P., Singh S. P., HÄDER D. P., 2010. Photoprotective compounds from marine organisms. J. Indust. Microbiol. Biotechnol. 37, 537558.

SingH J. S., 2013. Plant growth promoting rhizobacteria. Resonance 18, 275-281.

SingH J. S., SingH D. P., 2013. Plant growth promoting Rhizobacteria (PGPR): microbes in sustainable agriculture. [W:] Management of microbial resources in the environment. Malik A., GROHMAN E., Alves M. (red.). Springer, Dordrecht, 361-385. Singh J. S., Kumar A., RaI A. N., Singh D. P., 2016. Cyanobacteria: A Precious bio-resource in agriculture, ecosystem, and environmental sustainability. Front. Microbiol. 7, 529.

SingH V., Chaudhary D. K., Mani I., DHaR P. K., 2016. Recent advances and challenges of the use of cyanobacteria towards the production of biofuels. Renew. Sustain. Energy Rev. 60, 1-10.

SODAEIZADEH H., HosseinI Z., 2012. Allelopathy an environmentally friendly method for weed control. International Conference on Applied Life Sciences. Turkey, 387.

SRIRANGAN K., PYNe M. E., ChOU C. P., 2011. Biochemical and genetic engineering strategies to enhance biohydrogen production in photosynthet ic algae and cyanobacteria. Bioresource Technol. 102, 8589-8604.

TANTICHAROEN M., REUNGJITCHACHAWALI M., Boonag B., Vondtaveesuk P., VonshaK A., Cohen Z., 1994. Optimization of $\mathrm{\gamma}$-linolenic acid (GLA) production in Spirulina platensis. J. Appl. Phycol. 6, 295-300.

TORRes A., Enk C. D., HochBerg M., SREBNIK M., 2006. Porphyra-334, a potential natural source for UVA protective sunscreens. Photochem. Photobiol. Sci. 5, 432-435.

TREDICI M. R., 2010.Photobiology of microalgae mass cultures: understanding the tools for the next green revolution. Biofuels 1, 143-162.

VAZOUEZ-MARTINEZ M. G., RODRÍGUEZ M. H., ARREDONDO-JiméneZ J. I., MéndeZ-SÁncheZ J. D., BOND-COMPEÁN J. G., GOLD-MORGAN M., 2002. Cyanobacteria associated with Anopheles albimanus (Diptera: Culicidae) larval habitats in southern Mexico. J. Med. Entomol. 39.6, 825-832.

VONSHAK A., 1997. Spirulina platensis (Arthrospira): Physiology cell-biology and biotechnology. Taylor \& Francis, Londres.

Werle C. O., Trendel O., ARdito G. 2013. Unhealthy food is not tastier for everybody: The "healthy = tasty" French intuition. Food Quality Preference 28, 116-121.

YANG L. L., ZHOU Q. J., WANG Y., GAO Y., WANG Y. Q., 2012. Comparison of the therapeutic effects of extracts from Spirulina platensis and amnion membrane on inflammation-associated cor neal neovascularization. Int. J. Ophthalmol. 5, 32-37.

Yoshino F., IKEDA H., Masukawa H., SAKURA H., 2007. High photobiological hydrogen production activity of a Nostoc sp. PCC 7422 uptake hydrogenase-deficient mutant with high nitrogenase activity. Marine Biotechnol. 9, 101-112.

KOSMOS Vol. 67, 4, 0-000, 2018

Kinga Dobosz, Julia Tuszer-Kunc, Dagmara Kulasa, Sylwia Śliwińska-Wilczewska

Institute of Oceanography, Faculty of Oceanography and Geography, University of Gdansk, 46 Piłsudskiego Str., 81-378 Gdynia, E-mail: dobosh1994@gmail.com

\section{UTILIZATION OF CYANOBACTERIA IN MASS CULTURES}

\section{Summary}

Cyanobacteria mass production has been known since XVI century. In recent years, it has gained popularity owing to rapid growth, low environmental requirements and special properties of these microorganisms. Cyanobacteria contain high amounts of vitamins, minerals, proteins and polyunsaturated fatty acids. They are used in the food industry and in the production of cosmetics, medicines and in wastewater treatment technologies or removal of biogenic compounds. The most commonly used species is Arthrospira platensis, known as "spirulina", of a high economic, ecological and nutritional value. Some cyanobacteria, due to the rapid growth, are used as food for animals. It was found that metabolites obtained from these organisms can be used as herbicides and insecticides, so they can play an important role in agriculture. There are also some species of cyanobacteria, which are particularly studied in terms of biofuel production, so they could also become a source of renewable energy. 